Canadian University Music Review

Revue de musique des universités canadiennes

\title{
From Le sacre to Les noces: Primitivism and the Changing Face of Modernity
}

\section{Nancy Berman}

Volume 20, numéro 1, 1999

URI : https://id.erudit.org/iderudit/1015645ar

DOI : https://doi.org/10.7202/1015645ar

Aller au sommaire du numéro

\section{Éditeur(s)}

Canadian University Music Society / Société de musique des universités canadiennes

\section{ISSN}

0710-0353 (imprimé)

2291-2436 (numérique)

Découvrir la revue

\section{Citer cet article}

Berman, N. (1999). From Le sacre to Les noces: Primitivism and the Changing Face of Modernity. Canadian University Music Review / Revue de musique des universités canadiennes, 20(1), 9-21. https://doi.org/10.7202/1015645ar

\section{Résumé de l'article}

The function of the primitivist aesthetic in modern French culture shifted dramatically from the pre- to the post-war period. Whereas the primitivism of the Ballets russes's Le sacre du printemps was understood by its contemporaries to be radical, excessive, even prophetic and apocalyptic, the primitivism of Les noces was perceived to some extent as a manifestation of both the classicist "call to order" and the mechanistic aesthetic of the post-war period. Indeed, Les noces was one of many cultural products by means of which post-war modernists extolled the virtues of the machine age.
All Rights Reserved @ Canadian University Music Society / Société de musique des universités canadiennes, 2000
Ce document est protégé par la loi sur le droit d'auteur. L'utilisation des services d'Érudit (y compris la reproduction) est assujettie à sa politique d'utilisation que vous pouvez consulter en ligne.

https://apropos.erudit.org/fr/usagers/politique-dutilisation/ 


\title{
FROM LE SACRE TO LES NOCES: PRIMITIVISM AND THE CHANGING FACE OF MODERNITY ${ }^{1}$
}

\author{
Nancy Berman
}

From the turn of the century until the First World War, the emerging modernist movement in European arts and literature was, ironically, characterized by its disapproval of modernity. ${ }^{2}$ The early modernists, according to Charles Taylor, protested "a world dominated by technology, standardization, the decay of community, mass society, and vulgarization"; 3 they were overcome with a sense that Europe was reaching the end of an epoch, the end, as Thomas Mann wrote in his novel The Magic Mountain, of "the bourgeois, humanistic, liberal epoch, which was born at the Renaissance and came to power with the French Revolution, and whose last convulsive twitchings and manifestations of life we are now beholding." 4 Modern society was perceived to be increasingly and tragically estranged from the earth; human culture was becoming, in the words of the Russian poet Alexander Blok, "ever more a thing of iron, of machines; more and more it resembles a gigantic laboratory in which vengeance upon stikhiya [elemental spontaneity] is made ready; science grows so as to enslave the earth ..." Mann and Blok were among the many who echoed the sentiments

1 This is a revised version of a paper presented at the 1998 conference of the Canadian University Music Society in Ottawa, where it was awarded the George Proctor Prize jointly with Laurel Parsons's paper entitled "Music and Text in Elisabeth Lutyens's Wittgenstein Motet," also published in this issue. I would like to acknowledge the assistance of the Social Sciences and Humanities Research Council of Canada for a Fellowhip which enabled me to travel to Paris in the summer of 1994 to research primary sources.

2 See Peter Gay, Freud, Jews, and Other Germans: Masters and Victims in Modernist Culture (New York: Oxford University Press, 1978), 22: “Modernists hated modernity: they hated, in other words, the rule of the machine, the vulgarity of bourgeois society, the pretensions of parvenus, the waning of community"; Lionel Trilling, Beyond Culture (New York: Viking Press, 1965), 19, where he characterizes the modern element in literature as "hostility to civilization," the "canonization of the primal, non-ethical energies ... the disenchantment of our culture with culture itself"; and Clement Greenberg, "Modernist Painting," in Modern Art and Modernism: A Critical Anthology, ed. Francis Frascina and Charles Harrison with the assistance of Deirdre Paul (New York: Harper and Row, 1982), 5: "I identify Modernism with the intensification, almost the exacerbation, of th[e] self-critical tendency that began with the philosopher Kant ..."

3 Charles Taylor, Sources of the Self: The Making of the Modern Identity (Cambridge, Mass.: Harvard University Press, 1989), 456.

4Thomas Mann. The Magic Mountain (New York: Alfred A. Knopf, 1944 [c. 1927]), quoted in Ricardo J. Quinones, Mapping Literary Modernism: Time and Development (Princeton, N.J.: Princeton University Press, 1985), 24.

5 Alexander Blok, "Poèziya zagovorov i zaklinaniy," in Sobraniye sochineniy v shesti tomakh, vol. 5 (Moscow: Izdatel-stvo "Pravda," 1971), as quoted in Richard Taruskin, Stravinsky and the Russian Traditions (Berkeley and Los Angeles: University of California Press, 1996), 1:850. 
pervading cultural life at the beginning of the century: Joseph Conrad, D. H. Lawrence, T. S. Eliot, and Virginia Woolf also emphasized in various ways the sense of disenchantment, decay, and degeneracy prevalent at the time, as did artists such as Gauguin, Picasso, Vlaminck, Matisse, Kandinsky, Kirchner, and Klee, among many others. All of these writers and artists turned at some point in their careers to the primitive, searching for a revitalizing force for art, for psychological and cultural beginnings and origins, for a means to transcend Western degeneracy; what these artists and writers ultimately found, however, was themselves, both as individuals and as members of modern European society.

Primitivism erupted into the modernist vanguard with unprecedented frenzy on 29 May 1913 at the Théâtre des Champs-Élysées in Paris. The premiere of Stravinsky's Le sacre du printemps marked, to borrow Lionel Trilling's phrase, the "canonization of the primal, non-ethical energies" in music and dance. ${ }^{6}$ The critical uproar following the premiere has become part of musicological lore. Indeed, the legendary riot and subsequent flurry of activity in the daily and periodical press contribute to our present-day reception of the work as a landmark of modernity, a monolith of twentieth-century music. The reception history of Le sacre holds more than mythological value, however; it clearly reveals the significance of the work's perceived primitivism within the early modern movement. ${ }^{7}$

If the Ballets russes's production of Le sacre provided passage to a land of primitive ritual, its Parisian audience approached this image of pagan Russia as an Other against which it could assert or question its own identity, and onto which it could project its own fears and desires. ${ }^{8}$ Thus, in the press, the "primitive" Russians were repeatedly aligned with nature, being described as animalistic, devoid of reason, corporeal, violent, unable to restrain their impulses, while the French were always aligned with culture and civilization, with centuries of experience, with reason, wisdom, restraint, and finesse. For the more nationalistic critics, these binarisms served to confirm French cultural superiority; for the progressive, avant-garde, modernist critics, the Russians' youthful, uninhibited traits served to foreground, and thus question, the degeneracy and overly cerebral aspects of French culture. ${ }^{9}$

6Trilling, Beyond Culture, 19.

7The entire reception history of the 1913 premiere of Le sacre has been collected by Truman Campbell Bullard in his dissertation, "The First Performance of Igor Stravinsky's Sacre du Printemps," 3 vols. (Ph.D. diss., The University of Rochester, Eastman School of Music, 1971). In addition to collecting and translating the reviews, Bullard discusses the context and parameters of the critical reaction; he does not, however, address the issue from the standpoint of cultural history. See also Igor Stravinsky-Le Sacre du Printemps: Dossier de Presse, collected by François Lesure (Genève: Éditions Minkoff, 1980). This collection offers reviews and articles from several cities, including Paris, London, St. Petersburg, Moscow, Berlin, Rome, Buenos Aires, and New York. Preponderance of place is given to articles and reviews concerning the Paris premiere; however, reviews of both the 1920 version with choreography by Massine, and the concert version, are included.

8 Here I am borrowing from discourse theory as established by, among others, Edward Said in Orientalism (New York: Pantheon Books, 1978).

9For a good example of the nationalistic viewpoint, see Jean Perros, "Après les Ballets Russes," 
In this article I will argue that the function of the primitivist aesthetic in modern French culture shifted dramatically from the pre- to the post-war period. Whereas the primitivism of Le sacre was understood by its contemporaries to be radical, excessive, even prophetic and apocalyptic, the primitivism of Les noces was perceived to some extent as a manifestation of both the classicist "call to order" and the mechanistic aesthetic of the post-war period. While Le sacre conformed to the pre-war stance of the modernists-that is, its modernist supporters perceived it to be critical of modern French culture and society-Les noces was one of many cultural products by means of which post-war modernists extolled the virtues of the machine age. ${ }^{10}$

At a very basic level, the primitivist rhetoric remained constant in the reception of both Le sacre and Les noces. In the reception of Les noces, the primitive continued to be defined as instinctive, youthful, and natural; in both Le sacre and Les noces, primitivism's primary musical sign was understood to be rhythm; for both works, the dancing masses provided the foremost choreographic sign. Henry Malherbe best described the dancing masses in his review of the premiere of Les noces, in the Feuilleton du Temps of 27 June 1923: "These rhythmic swarmings of a Russian crowd, these complicated maneuvers of an unarmed troop, whipped by the sonorous knout of a brutal music, these pyramids of anxious gymnasts, these jumps of louts, these torturing exercises of a squad, under the orders of the implacable amazon that is Mlle Nijinska ..."11

La Critique indépendante 8, no. 11 (15 June 1913), in Bullard, "The First Performance of Igor Stravinsky's Sacre du Printemps," 3:136-37; for an example of a modernist standpoint, see RolandManuel, "Le Sacre du Printemps," Montjoie! (14-29 June 1913), in ibid., 3:174. See also chapter 2 of Nancy Berman, "Modern Primitivism: The Parisian Avant-garde, 1910-1925" (Ph.D. diss., McGill University, forthcoming).

10 In this paper I will focus primarily on the reception of Les noces. Supporters of Le sacre who saw the work as critical of modern French culture include Jacques-Émile Blanche, who claimed that the Ballets russes revealed and protested the "regrettable individualism," "particularism," "decadence," and "poverty" which in his opinion characterized contemporary French culture; "Un bilan artistique de 1913," La Revue de Paris, 1 December 1913, 517-34, in Bullard, "The First Performance of Igor Stravinsky's Sacre du Printemps,"1:312-13, 316, 336. Jean Marnold also comments on the decadence of the French tradition and the manner in which the Ballets russes, in their production of Le sacre, challenge the conventions of French culture; see Jean Marnold, "Musique," Mercure de France, 1 October 1913, 623-30, in Bullard, 1:250. Indeed, many were the critics who commented on the challenge posed to French culture by the Ballets russes and Le sacre. See, for example, Octave Maus, "Le Sacre du Printemps," L'Art moderne 33, no. 22 (1 June 1913): 169-70, in Bullard, 1:72; Florent Schmitt, "Les premières: Les Sacres du Printemps de M. Igor Stravinsky au Thêâtre des Champs-Elysées," La France 52, no.154 (4 June 1913): 2, in Bullard, 1:94; Fernand Gregh, "Ce que disent les danses du Prince Igor," La Revue musicale 9, nos. 7-8 (July-August 1913): 8-11, in Bullard, 1:205; René Chalupt, "Le mois du musicien," La Phalange 8 (20 August 1913): 169-75, in Bullard, 1:224; Louis Laloy, "Stravinski," La musique retrouvée (Paris: Librairie Plon, 1928), 214-19, in Bullard, 1:231. Ironically, the conservative arch-nationalist critic Jean Perros most aptly summarizes the modernist view of Le sacre (which he despised) in his review "Après les Ballets russes," La Critique indépendante 8, no. 11 (15 June 1913): 1, in Bullard, 1:153-54; here his sarcastic take on the work and those who worshipped the Ballets russes reveals to what extent the Russians were perceived to both challenge and threaten French culture and civilization.

11 "Ces fourmillements rythmés d'une foule russe, ces manœvres compliquées d'une milice désarmée, fouettée par le knout sonore d'une musique brutale, ces pyramides de gymnastes anxieux, ces sauts de lourdauds, ces exercices torturants d'une escouade, sous les ordres de l'implacable amazone qu'est Mlle Nijinska ..." (translation by Drue Fergison, who has collected and translated many of the reviews of 
There are, however, substantial differences in the reception of the primitivist aesthetic as manifest in Le sacre and Les noces. For Les noces, unlike Le sacre, was repeatedly described by the critics in terms of its simplicity, austerity, purity, stripped down sobriety, and, most surprising of all, its classicism. ${ }^{12}$

Many of the most qualified critics used the term "classical" to differentiate Les noces from Le sacre. Roland-Manuel, a prominent composer, writer and popularizer of music, compared the romanticism of Le sacre to the classicism of Les noces: "Neighbours, at a distance, in spirit, Le sacre and Les noces differ curiously in terms of structure ... The peculiar romanticism of Le sacre gives way to a sort of grand, stripped-down classicism, which clearly emphasizes an orchestral arrangement whose simplicity is extremely bold." 13 Boris de Schloezer, another prominent critic, writing for La Nouvelle Revue francaise, claimed that Nijinska's choreographic style was "classicism in the large sense"; 14 Yvonne Sérac, in Tentatives, wrote of the alliance of the classic and the modern. ${ }^{15}$ André Levinson, one of the epoch's most prominent dance critics, implied the classical aspect of Les noces when he compared it to Picasso's "Ingrist" works. ${ }^{16}$

the premiere of Les noces in her dissertation "Les Noces: A Microhistory of the Paris 1923 Production" [Duke University, 1995]). Henry Malherbe, "Aux Ballets Russes: Noces, scènes chorégraphiques russes avec chant et musique composées par M. Igor Strawinsky," Feuilleton du Temps, 27 June 1923. A knout was a type of whip used in imperial Russia for purposes of torture, with death often the final result.

12For examples of critics who use terms such as these, see Albert Jeanneret, "Noces," L'Esprit nouveau, no. 18 (no page): "Gontcharova, usually turbulent and sometimes rowdy, here maintains an excellent sobriety of the purest effect" ("Gontcharowa, dont on sait la turbulence habituelle, parfois tapageuse, est ici d'une excellente sobriété de l'effet le plus pur"); no author, "Les revues et la presse, Dernier écho de 'Noces,"' La Revue musicale, November 1923, 93: "The technique in Noces is related to that of Le Sacre; but, overall, the work is more plastic, with purer contours; colour is relegated to the background" ("Pour la technique les Noces s'apparentent au Sacre; mais, dans l'ensemble, l'œuvre est plus plastique, des contours plus purs; la couleur est reléguée au second plan"); Raymond Charpentier, Georges Linor, and André Levinson, "Les Ballets Russes à la Gaîté-Lyrique: 'Noces'. Ballet de M. Igor Stravinsky," Comoedia, 16 June 1923, section entitled "Le décor, la chorégraphie," by André Levinson: "Austerity appears here as excessive as was the voluptuousness of orgiastic colour not long ago" ("L'austérité y apparaît aussi excessive que l'était naguère la volupté des coloris orgiaques"); Gustave Bret, "Les Noces," L'Intransigeant, 16 June 1923, 2: "Music without artifice and without clothing, sturdy, dry, and naked" ("Musique sans fard et sans vêtements, drue, sèche, et nue"); Yvonne Sérac, "Les Noces, "Tentatives, 15 August 1923, 90-91: "stripped of all their richness and luster" ("dépouillés de tout ce qui fut leur richesse et leur éclat"). Translations mine; henceforth, all translations my own unless otherwise indicated.

13 "Voisines, de loin en loin, par l'esprit, le Sacre et les Noces different curieusement d'aspect et de structure ... Le romantisme particulier du Sacre laisse la place à une espèce de grand classicisme dépouillé, que met nettement en valeur une disposition orchestrale dont la simplicité est extrêmement hardie..." Roland-Manuel, "La quinzaine musicale-Les Ballets Russes à la Gaîté-Lyrique: Les Noces d'Igor Stravinsky," L'Éclair, 25 June 1923.

14 "classicisme au sense large"; Boris de Schloezer, "Noces," La Nouvelle Revue française, 24 June 1923, 247.

15 "l'alliance du classique et du moderne"; Yvonne Sérac, "Les Noces," Tentatives, 15 August 1923, 90-91.

16Charpentier, Linor, and Levinson, "Les Ballets Russes à la Gaîté-Lyrique," Comoedia, 16 June 1923, section on "Le décor, la chorégraphie," by Levinson: "By force, the artist inscribes colourless Russian folklore in the firm contour of Picasso's so-called 'Ingrist' designs" ("De force, l'artiste inscrit le folklore russe décoloré dans le contour ténu des dessins dit 'ingristes', de Picasso"). 
Classicism, austerity, purity, sobriety: by 1923 , the significance of these vital cultural catchphrases was multifaceted. As early as the beginning of the century, French critics, reflecting the growing anti-Germanic and anti-Romantic sentiments of French composers, had begun to establish a definition of classicism founded on "clarity, simplicity, austerity, sobriety, pure construction, precision, discreet harmony, and formal perfection."17 After World War I, this conglomerate of aesthetic attributes came to be applied to the emerging avant-garde trend that first made its appearance in the visual arts during the war, the nouveau classicisme. As Scott Messing explains, until the 1920s, the nouveau classicisme remained more or less distinct from what we now refer to as "neoclassicism" (that is, the use of pre-Romantic formal procedures by twentieth-century composers). The former was described by Maurice Brillant, in an essay written in 1921, as a style which emphasized "great care of construction, a great austerity, and a sobriety provoked by renunciation of impressionist colours." 18 Neoclassicism, on the other hand, maintained the pejorative connotation that had been associated with it since the turn of the century, until 1923, the year of the premieres of Stravinsky's Octet and his Pulcinella. ${ }^{19}$ Only in the early 1920 s, then, did the term "neoclassicism" lose its derogatory meaning, and come to imply both tradition (through its reliance on pre-Romantic formal procedures) and innovation (through its use of the anti-Romantic language of the avant-garde). For the critics, the classicism of Les noces (which premiered on the same program as the neoclassical Pulcinella) was not dependent on the use of pre-Romantic formal maneuvers; it referred solely to what was perceived to be its use of the avant-garde language of the time, to its bare, austere, simple, essential nature, to the transformation of real life actions into ritual gesture into "pure" plastique. ${ }^{20}$ The perceived

17 Scott Messing, Neoclassicism in Music: From the Genesis of the Concept through the Schoenberg/Stravinsky Polemic, Studies in Musicology, no. 101 (Ann Arbor: UMI Research Press, 1988), 10.

18Maurice Brillant, "Les œuvres et les hommes," Le Correspondant, 25 February 1921, 744-45, quoted in Messing, Neoclassicism in Music, 81.

19 According to Messing, at the turn of the century, French critics often used the term "neoclassicism" to describe the music of Brahms and Mahler, who, in their opinion, "sacrificed originality and depth of musical substance for the abject imitation of structure" (Neoclassicism in Music,14). See Messing, pp. $129 \mathrm{ff}$., for the connection of neoclassicism with Stravinsky. Messing claims that "[s]cholars do not agree on which Stravinsky opus is most appropriate to label as his first neoclassic composition; the majority opinion is divided between Pulcinella and the Octet. The expression, however, never appeared in reviews of the premieres of these works, and its attachment in 1923 to Stravinsky may have seemed random, occurring just at the moment when the terminology needed a composer of sufficient stature upon which it could be grafted in order to sustain its continued use" (p. 88).

20 See Boris de Schloezer, "Notes: Les Noces," La Nouvelle Revue francaise, August 1923, 247 : "Les Noces is a picture of ancient Russian peasant wedding rites, but, as in the dances of Sacre, ... those of Noces have no anecdotal, descriptive, or archeologic signification: they are the transformation of ritual attitudes and gestures (themselves merely a symbolic transposition of real-life actions) into pure plastique" ("Les Noces sont un tableau des anciens rites nuptiaux de la Russie paysanne, mais de même que les danses du Sacre, ... celles des Noces n'ont aucune signification anecdotique, descriptive, archéologique: elles $s$ 'inspirent des gestes et attitudes rituels (lesquels eux-mêmes ne sont qu' une transposition symbolique des actions de la vie réelle) pour aboutir à leur transposition purement plastique"). 
classicism of Les noces was the hallmark of its modernism; the critics situated the work squarely within the "call to order" which had been articulated by Cocteau in his book Le coq et l'arlequin in 1918 (reprinted in 1926 as Le rappel à l'ordre) and which dominated modernist tendencies in France throughout the $1920 \mathrm{~s}^{21}$ Furthermore, the aesthetic attributes associated with both neoclassicism and nouveau classicisme were shared with the primitivist tendencies of the period. ${ }^{22}$

While many post-war modernists advocated the austerity and sobriety of the new classicism, no group of artists explored so thoroughly the intimate relationship between the classic and the modern as did the Purists, in the pages of their review L'Esprit nouveau. An exploration of the Purists' modernist affinity for the classical, an affinity which characterized the reception of Les noces, will allow us insight into the work's multi-dimensional primitivism.

L'Esprit nouveau was founded in November 1921 by the architect CharlesÉdouard Jeanneret (later to come to fame as Le Corbusier, one of the leading architects of the twentieth century), his good friend the painter Amédée Ozenfant, and the poet Paul Dermée. An important voice for the Parisian avant-garde, this magazine of "general progressive culture" embraced fields as diverse as architecture, painting, sculpture, product design, music, literature, philosophy, psychology, politics, and economics. ${ }^{23}$ Despite the diversity of subject matter, the aesthetic views of its editors revealed a particular overriding sensibility. An emphasis on reason, logic, mathematics, science, mechanization, and technology pervaded its pages: ${ }^{24}$ the editors and contributors were committed to "order, precision, to the lesson of the engineer and the machine, to the classical tradition." 25

Inasmuch as it reflected "an artistic climate that placed its faith in formal, pure, objective values," Purism participated in the large-scale call to order which dominated French cultural life after World War I. ${ }^{26}$ According to the art historian Romy Golan, the Purists

21 Jean Cocteau, CEuvres complètes (Geneva: s.n., 1946-51). For more on Cocteau's aesthetic vision and its context, see Messing, Neoclassicism in Music, 79.

22Messing, in Neoclassicism in Music, 111, also observes this connection: "Our survey of contemporary appraisals of Stravinksy's music after Le sacre du printemps has demonstrated that the rhetoric of simplicity, childhood, and objectivity was a shared affinity with French modernist trends in music, literature, and the visual arts. We may, however, recognize another concurrent tendency which was also characterized by a similar language of purity, concision, and naiveté: the influence of non-Western primitive cultures on the European avant-garde. In 1916, when Egon Wellesz observed that 'the sudden and wide-spread interest in primitive music, in folk-music, and in the music of savage races seems to indicate that this new tendency has already received its theoretical foundation,' he was stating an already obvious cliché."

23 Reyner Banham, Theory and Design in the First Machine Age (London: The Architectural Press, 1960), 208.

24 See Christopher Green, Léger and the Avant-garde (New Haven and London: Yale University Press, 1976), 203, 204, 209, 211, 243-44; Banham, Theory and Design, 207-10; John Golding and Christopher Green, Léger and Purist Paris. The Tate Gallery, 18 Nov. 1970-24 Jan. 1971 (London: Tate Gallery, 1970); Romy Golan, "Modes of Escape: The Representation of Paris in the Twenties," in The 1920s: Age of the Metropolis, exhibition catalogue, ed. Jean Clair (Montreal: The Montreal Museum of Fine Arts, 1991), esp. 336-45.

25Green, Léger and the Avant-garde, 7. 
advocated a pictorial syntax based on mathematical measurements, universal laws, stability, solidity and a striving towards perfect harmony. If the War had left behind piles of debris, Purism, both antidote and cure, prescribed a world-as this self-coined "ism" plainly indicated—of utter purity. ${ }^{27}$

The basis of the Purist aesthetic was reason: for Jeanneret and Ozenfant, reason regulated not only scientific inquiry, but also artistic undertaking:

Nothing justifies us in supposing that there should be any incompatibility between science and art. The one and the other have the common aim of reducing the universe to equations. We shall prove that pure art and pure science are not watertight domains. They have a common mind ... art and science depend on number. ${ }^{28}$

The Purists greatly admired modern machines as well as the esthétique mécanique, or the mechanical aesthetic. ${ }^{29}$ Indeed, the second paragraph of the first issue of L'Esprit nouveau emphasizes the importance of the machine aesthetic:

Today no-one denies the aesthetic that is revealed by the constructions of modern industry. More and more, the construction of industrial machines relies on proportions, the play of volumes, and material in such a way that many of them are veritable works of art, because they involve number, that is, order. Now, the elite, individuals who make up the world of industry and business, and who consequently live in this virile atmosphere where undeniably beautiful works are created, believe themselves to be quite far from all aesthetic activity; they are wrong, because they are among the most active creators of the contemporary aesthetic ... it is in general output that one finds the style of an epoch, and not, as we too often believe, in a few ornamental productions. ${ }^{30}$

26Golding and Green, Léger and Purist Paris, 7. See also Golan, "Modes of Escape," 336: "The most immediate impulse at the end of World War I was for a return to order, and nowhere was this yearning more evident than in the emergence of Purism."

27 Ibid.

28Quoted in Banham, Theory and Design, 207; see also Green, Léger and the Avant-garde, 204.

29 See Green, Léger and the Avant-garde; Golding and Green, Léger and Purist Paris; Kenneth Silver, Esprit de corps: The Art of the Parisian Avant-garde and the First World War, 1914-1925 (Princeton: Princeton University Press, 1989).

30"Nul ne nie aujourd'hui l'esthétique qui se dégage des constructions de l'industrie moderne. De plus en plus les constructions industrielles, les machines s'établissent avec des proportions, des jeux de volumes et de matières tels que beaucoup d'entre elles sont de véritables œuvres d'art, car elles comportent le nombre, c'est-à-dire l'ordre. Or, les individus d'élite qui composent le monde de l'industrie et des affaires et qui vivent par conséquent dans cette atmosphère virile où se créent des œuvres indéniablement belles, se figurent être fort éloignés de toute activité esthétique; ils ont tort, car ils sont parmi les plus actifs créateurs de l'esthétique contemporaine. ... c'est dans la production générale que se trouve le style d'une époque et non pas, comme on le croit trop, dans quelques productions à fins ornementales." $L$ 'Esprit nouveau, no. 1: no page. 
Although the Purists often drew analogies between the machine and the work of art, they never advocated making machines the subject of paintings. ${ }^{31}$ Furthermore, although they championed modernity and mass production, the Purists maintained a strict, hierarchical division between high and low art, fine art, and mass culture. ${ }^{32}$ Analogies between the machine and the work of art were extended by many artists in the 1920s, such that the machine was used as a metaphor for psychological states of mind..$^{33}$

For Le Corbusier and Ozenfant, the new Machine Age heralded a new classical age. Their works exemplify this belief inasmuch as their mechanistic qualities (for example, the overlapping of objects which results in the outlines of cogwheels and pistons) always coexist with allusions to classical art and architecture ${ }^{34}$ For the Purists, objects such as the aeroplane, the steamship, and especially the motorcar served to link modern aesthetic values and mechanization with the classical, "pure" aesthetic values of ancient Greece. These objects, which before the war had been symbols of dynamic simultaneity, became, after the war, symbols of a new, mechanized "call to order," more in touch with committed, modern-life realism. ${ }^{35}$

For the Purists, then, modernism, and specifically its machine technology, hearkened back to the aesthetic purity of classical Greece. And indeed, perhaps the most striking aspect of the critical reception of Les noces is the emphasis placed not only on its modern classicism, but also on its machine aesthetic.

Émile Vuillermoz, a composer and music critic whose enormous role in French cultural life spanned more than fifty years, ${ }^{36}$ attributed the special

31 Green, Léger and the Avant-garde, 265. One of the painters best known for his mechanical aesthetic was Fernand Léger, himself a member, in the first half of the 1920s, of the Purist group. While the Purists' belief in the analogy between the work of art and the machine led them to tolerate and even admire artists such as Léger who actually incorporated the machine into their work, his trademark paintings of machines are not considered to be representative of the Purist aesthetic; rather his Paysages animés of the early 1920s best reflect the Purist view of art and life, specifically the relationship between man, nature and architecture. See Green, 250-85.

32 Golan, "Modes of Escape," 339.

33See Golan's discussion of Suzanne Duchamp and Jean Crotti in "Modes of Escape," 361.

34 Ibid., 337.

35Simultaneity refers to a mode of representation explored by the Cubists, the Orphists, and the Futurists, in which more than one view of the same person or object is presented to the viewer. One of the primary practitioners of simultaneous representation was Robert Delaunay (1885-1941), whose Orphist style grew out of the desire to bring more lyricism and colour to the austere intellectual Cubism of Picasso, Braque, and Gris (other artists concerned with simultaneity include Léger, Picabia, Duchamp, and Kupka). The Orphists' concern with dynamism and dynamic simultaneity is aptly summarized in the following excerpt from the "Technical Manifesto of Futurist Painting," published in Comoedia on 18 May 1910: "The gesture which we would reproduce on canvas shall no longer be a fixed moment in the universal dynamism. It shall simply be the dynamic sensation itself. Indeed, all things move, all things run, all things are rapidly changing. A profile is never motionless before our eyes, but it constantly appears and disappears. On account of the persistency of an image upon the retina, moving objects constantly multiply themselves; their form changes like rapid vibrations, in their mad career. Thus, a running horse has not four legs, but twenty, and their movements are triangular" (Umbro Apollonio, ed., Futurist Manifestos [New York: Viking Press, 1973], 27-28). See Sherry A. Buckeberrough, Robert Delaunay: The Discovery of Simultaneity, Studies in the Fine Arts: The Avant-garde, no. 21 (Ann Arbor: UMI Research Press, 1982).

36Vuillermoz, a promoter of modern music, was instrumental, with Charles Kœchlin, in setting up 
quality of Les noces to its machine aesthetic: while Les noces was, for him, an aesthetic extension of Le sacre, its special atmosphere, sustained by music both savage and barbaric, was created by Stravinsky's "sound factory":

All he [Stravinsky] needs, to create his special pathos, is a solid machine with which to forge beautiful accents, a machine to hit, a machine to lash, a machine to fabricate automatic resonances. His genius resides in the organization of the rhythmic gasping of this sound factory, a gasping so new, so strong, so right, which dominates you, which carries you along, which subjects you to its fantasy without a reviving break. ${ }^{37}$

In a slightly later article, Vuillermoz took his analogy even further:

It is impossible to describe the irresistible effect of Stravinskyian rhythm, which is always unpredictable and unexpected, always accurate. Don't take what follows for a joke: if I was the director of a big metallurgical factory, if I had at my disposal, for example, the workshops of Creusot, I would not hesitate to organize a big celebration for the apotheosis of modern labour, and I would entrust Igor Stravinsky with the task of composing a score using the very instruments of work ... with a few simple yet striking melodies given to the crowd of workers. I am certain that I would thus permit the author of $L e$ Sacre to write, to the glory of iron and fire, an extraordinary masterpiece. ${ }^{38}$

Vuillermoz was not the only critic to liken Les noces to a sound factory. Roland-Manuel, in L'Éclair, described the instrumentation in terms of Stravinsky's "factory," overseen by the "engineer" Ernest Ansermet: "Under the surveillance of the chief engineer Ansermet ... the machines from the Stravinsky factory obtain, in Les noces, an output which surpasses the most optimistic forecasts." 39 Gustave Bret, writing in L'Intransigeant, made a similar analogy: "All of this [the instrumentation] creating an implacable sonorous factory, turbulent and precise, of a dynamic efficiency, superior to everything

the Société musicale indépendante in 1909; he became editor-in-chief of the Revue musicale in 1911, and contributed prolifically to L'Illustration, L'Éclair, and Comoedia.

37 “il n'a besoin, pour créer son pathétique spécial, que d'une solide machine à forger de beau accents, machine à frapper, machine à cingler, machine à fabriquer des résonances automatiques. Son génie réside dans l'organisation du halètement rythmique de telle usine sonore, halètement si nouveau, si fort, si juste, qui vous domine, qui vous entraîne, qui vous asservit à sa fantaisie sans cesse renaissante." Émile Vuillermoz, "Premières. Ballets Russes: 'Noces,"' Excelsior, 18 June 1923, 5 (translation after Fergison).

38 "Il est impossible de décrire l'effet irrésistible du rythme strawinskyste, toujours imprévu et inattendu, toujours juste. Qu'on ne prenne pas ce qui va suivre pour une plaisanterie: si j'étais directeur d'une grande usine métallurgique, si j'avais à ma disposition, par exemple, les ateliers du Creusot, je n'hésiterais pas à organiser une grand fête du travail pour l'apothéose du labeur moderne, et je confierais à Igor Strawinsky le soin de composer une partition en se servant des instruments mêmes de ce travail $\ldots$ avec quelque mélopées très simples mais frappantes confiées à la foule des ouvriers. Je suis certain que je permettrais ainsi à l'auteur du Sacre d'écrire, à la gloire du fer et du feu, un extraordinaire chef-d'œuvre." Vuillermoz, "Noces, d'Igor Stravinsky," La Revue musicale, 1 August 1923 (translation after Fergison).

39 "les machines de l'usine Stravinsky obtiennent, dans Noces, un rendement qui dépasse les prévisions les plus optimistes." Roland-Manuel, "Les Noces," L'Éclair, 25 June 1923. 
that has been done in the genre." 40 Albert Jeanneret, Le Corbusier's brother and fellow contributor to $L^{\prime}$ Esprit nouveau, drew on assembly line imagery to describe Stravinsky's instrumentation; ${ }^{41}$ several other critics used the term "mechanical" to describe the effect of Les noces. For instance, according to Dominique Sordet, writing in L'Écho national, Stravinsky's aesthetic is "lit by the light of the choice of this singular sonorous material, whose properties are dryness, force, and mechanical cleanness." 42

Over the course of the nine years during which Stravinsky worked on Les noces, his own interest in the mechanical surfaced. ${ }^{43}$ Ramuz, in his Souvenirs sur Igor Strawinsky, tells of the years 1918-19, when Stravinsky was working on the orchestration for Les noces in Morges, a community which he described as "quite hostile to all novelty":

He [Stravinsky] even rivalled the carpenter's ribbon saw and the garage-owner's motors; and if I search for where his affinities would have been, where he would have found sympathy, it is not at the bourgeois apartments, of which there were so many in the vicinity ... it is in these workshops where the machines operated at full-speed as if in competition ... each part of the machine having its own particular sound and speed, while out of these superimposed sonorous elements a new rhythm was born; the multiple and conflicting aspects resulted in a rhythm both simple and persistent. ${ }^{44}$

40"Tout cela composant une usine sonore implacable, turbulente et précise, d'un rendement dynamique supérieur à tout ce qui a été fait dans le genre." Gustave Bret, "Ballets Russes: Noces, de Stravinsky," L'Intransigeant, 16 June 1923.

41 Albert Jeanneret, "Noces," L'Esprit nouveau, no. 18, n.p.

42"Toute l'esthétique de M. Stravinsky s'éclaire à la lumière du choix de ce singulier matériel sonore, dont les propriétés sont la sécheresse, la force, la netteté mécanique." Dominque Sordet, "La semaine musicale: Les Ballets Russes," L'Écho national, 25 June 1923.

43 Stravinsky began to compose Les noces in late summer 1914. He was interrupted by his work on Renard in 1915, and resumed intensive work on Les noces at the beginning of 1917. The short score was finished in April 1917. He then proceeded to score the first scene for an orchestra of 150. He wrote only a few pages using this orchestration, after which he experimented with separating the instrumental groups on stage. His next vision for the work's orchestration included an electrically driven mechanical piano and harmonium, an ensemble of percussion instruments and two Hungarian cimbaloms. After scoring the first two scenes along these lines, he realized the difficulty of finding two good cimbalon players, as well as the difficulty of synchronizing the mechanical elements with the singers and non-mechanical instrumentalists. Finally, in 1921, he found the definitive solution: choirs accompanied by a percussion orchestra divided into pitched and non-pitched instruments. The greater part of this instrumentation was carried out in 1922, and the orchestral score was completed on 6 April 1923. See Eric Walter White, Stravinsky: The Composer and His Works, 2nd ed. (Berkeley: University of California Press, 1979), 215-16.

44 "assez hostile à toute nouveauté ... Il concurrençait même la scie à ruban du menuisier, les moteurs du garagiste; et si je cherche où auraient dû être ses parentes et où il aurait dû trouver des sympathies, ce n'est pas à ces appartements bourgeois dont il y avait un grand nombre aux environs .... c'est à ces ateliers dont les machines fonctionnaient soudain à plein comme prises d'émulation; ... chaque organe de la machine ayant son bruit particulier et son allure particulière, tandis que de ces éléments sonores superposés et de leur superposition même naissait comme un rythme nouveau, dont la résultant était simple, persistante, les facteurs multiples et contrariés." Charles Ferdinand Ramuz, Souvenirs sur Igor Strawinsky (Lausanne: Éditions de l'Aire, 1978), 72-74. 
Given his interest in the mechanical, it is not surprising that Stravinsky's second version of Les noces, undertaken during his stay in Morges, includes a mechanical piano. ${ }^{45}$ Indeed Stravinsky's extensive reworking of the orchestration of Les noces was indicative of his search for the mechanical: in the words of the composer, the final instrumentation "would fulfill all my conditions. It would be at the same time perfectly homogeneous, perfectly impersonal and perfectly mechanical." 46 Stravinsky was to be the engineer and the inventor of what Jean-Michel Nectoux calls "perfectly oiled mechanisms." ${ }^{47}$ And indeed, the first audience for Les noces heard precisely that. ${ }^{48}$

As we have seen, classicism and the machine aesthetic are intricately linked in the reception of Les noces. With this context in mind, I would like now to explore the significance of the work's perceived primitivism. The worship of the machine and of modern technology prevalent in much of the French avant-garde reflects the obsession in France with America: machine-age America, with its industry, technology, and popular culture, was seen by the French as a land of promise, celebrated as "ultraperfect, rational and utilitarian and universal." 49 America represented the land of the future, the one "best equipped to usher in the new age: the naive master of the machine, unencumbered by the weight of tradition." 50 America and its machine age became viable as an alternative to tradition; poets and artists defined America "as a society of, by, and for the machine." 51

The view of America as free of tradition, existing in a permanent and vibrant present, dominated European thought from at least the nineteenth century. In 1887, the founder of the German Social Democratic Party, Wilhelm Liebknecht, commented that "[n]o traditions, no handed-down prejudices"

45 Stravinsky was to work with mechanical pianos for much of his career. See Rex Lawson, "Stravinsky and the Pianola," in Confronting Stravinsky, ed. Jann Pasler (Berkeley and Los Angeles: University of California Press, 1986), 284-301. Lawson (p. 293) believes that Stravinsky found escape from the demands and buffooneries of socialite Paris by working with mechanical pianos: "In a socialite Paris brimming with rich princesses, worthy musicians, and adoring acolytes, donning a metaphorical boiler suit and joining the musical mechanics must on occasion have been a great relief."

46 Igor Stravinsky and Robert Craft, Expositions and Developments (Berkeley and Los Angeles: University of California Press, 1981), 118.

47 See Jean-Michel Nectoux, "Stravinsky par lui-même: premiers enregistrements parisiens," Revue musicale de Suisse romande 38, no. 3 (September 1985):106: "The music from $L$ 'histoire du soldat and Ragtime, with their brief accents, their sharp sonorities, and their implacable ostinatos, illustrate well the intensity of the perfectly oiled mechanisms of which Stravinsky, like the sorcerer's apprentice, is the engineer and inventor" ("Les musiques d'Histoire du soldat et le Ragtime illustrent bien, avec leurs accents brefs, leurs sonorités acérées, leurs ostinatos implacable, cette vie intense de mécanismes parfaitement huilés dont Stravinsky serait l'ingénieur et l'inventeur quelque peu apprenti-sorcier").

48 Indeed, many of Stravinsky's critics and admirers were aware of his experiments with the player piano; his exploits were often publicized. This awareness could have further contributed to the reception of the work as "mechanical."

49El Lissitzky, “'Americanism' in European Architecture," Krasnaya Niva, no. 49 (1925), reproduced and translated in Sophie Lissitzky-Kuppers, El Lissitzky: Life, Letters, Texts (Greenwich, Conn.: New York Graphic Society, 1968), 369, quoted in Elizabeth Hutton Turner, American Artists in Paris, 1919-1929, Studies in the Fine Arts: The Avant-garde, no. 62 (Ann Arbor, Michigan: UMI Research Press, 1988), 46.

50Hutton Turner, American Artists in Paris, 2.

51 Turner, American Artists in Paris, 50, 59. 
prevented Americans from taking part in a "fresh, pulsating present." 52 Unencumbered by tradition, living in a constant present, youthful and naive: these typically primitivist catchphrases were consistently applied to America and American culture by Europeans, particularly in the post-war period; America became a new site by which France (and Europe in general) could transcend history's fate.

The benevolent, utopian primitivism associated with America's youthfulness, naïveté, and lack of tradition was complemented by the association of America with the putatively malefic presence of native Indians, and the activities of the "Wild West," all of which had been extensively popularized in Europe as early as 1826, the year in which James Fenimore Cooper's The Last of the Mohicans was published in French translation. Indeed, the presumed savagery of American Indians was a favourite source of entertainment in Europe throughout the nineteenth century: native Americans were imported to perform for European royalty, they were exhibited at zoological gardens, they were fantasized in Karl May's ever-popular novels, and they were prominently displayed in Buffalo Bill's Wild West Show from 1889 to 1906. Picasso himself painted Buffalo Bill and his Wild West Show in 1911.53

While Europeans obviously understood that there was a distinction between native Indians and "Americans," the spirit of the former seemed to infuse European perceptions of the latter. Writing in 1882, Nietzsche explained:

There is an Indian savagery, a savagery peculiar to the Indian blood, in the manner in which the Americans strive after gold: and the breathless hurry of their work - the characteristic vice of the New World-already begins to infect old Europe, and makes it savage also, spreading over it a strange lack of intellectuality ...54

America represented a strange but alluring amalgam of the primitive and the modern, where the rhythms of tribal music melded with the incessant rhythms of daily life and work-and particularly with the rhythms of the machines which the French admired and associated so strongly with the New World.

The fundamental point I wish to emphasize relates to Zeitgeist: that Les noces would be received as not only primitive, but also mechanical and classical in this atmosphere in which the avant-garde reveled can come as no surprise. After the war, modernists had come to terms with modernity, with the

52Quoted in Hugh Honour, The New Golden Land: European Images of America from the Discoveries to the Present Time (New York: Pantheon Books, 1975), 248.

53 See Glenn Watkins, Pyramids at the Louvre (Cambridge, Mass.: Harvard University Press, 1994), 90-91.

54Friedrich Nietzsche, "Sanctus Januarius: The Joyful Wisdom, Book IV," in The Complete Works of Friedrich Nietzsche, ed. Oscar Levy (London: T. N. Foulis, 1910), 10:254, quoted in Jean-Louis Cohen, Scenes of the World to Come: European Architecture and the American Challenge, 1893-1960 (Paris: Flammarion; Montreal: Canadian Centre for Architecture, 1995), 68; also quoted in Envisioning America: Prints, Drawings, and Photographs by George Grosz and His Contemporaries, 1915-1933, ed. Beeke Sell Tower (Cambridge, Mass.: Busch-Reisinger Museum, Harvard University, 1990), 14. 
rule of the machine and scientific progress. The primitive no longer served as an Other against which the West defined and transcended itself; the Parisian audience of Les noces adapted this most Russian of works as a reflection of its own, American-sponsored, machine-driven society. As Peter Wollen summarizes, while Orientalism, and, I would add, early (pre-World War I) primitivism, was crucial to the emergence of modern art, modernism was consolidated by Americanism, by

an aesthetic of the engineer obsessed by machine forms and directed against the lure of the ornamental and the superfluous ... [A]n art of the leisure class, dedicated to conspicuous waste and display, gave way to an art of the engineer, precise, workmanlike and production-oriented. This trend, which grew alongside and out of an interpretation of cubism, culminated in a wave that swept across Europe: Soviet constructivism, the Bauhaus, De Stijl, purism, Esprit Nouveau. All of these were variants of an underlying functionalism which saw artistic form as analogous to (or even identical with) machine form, governed by the same functional rationality. ${ }^{55}$

In Les noces, the sound of the Russian peasant merges with the sound of the American worker: the folk rhythms which propel the mundane cycles of life conflate with the factory rhythms which propel Europe out of its own disturbing past and forward into the machine age; the echoes of age-old tradition are transformed into the incessant beat of the new.

\begin{abstract}
The function of the primitivist aesthetic in modern French culture shifted dramatically from the pre- to the post-war period. Whereas the primitivism of the Ballets russes's Le sacre du printemps was understood by its contemporaries to be radical, excessive, even prophetic and apocalyptic, the primitivism of Les noces was perceived to some extent as a manifestation of both the classicist "call to order" and the mechanistic aesthetic of the post-war period. Indeed, Les noces was one of many cultural products by means of which post-war modernists extolled the virtues of the machine age.
\end{abstract}

55 Peter Wollen, Raiding the Icebox: Reflections on Twentieth-century Culture (Bloomington: Indiana University Press, 1993), 35, 13. 